University of Nebraska - Lincoln

DigitalCommons@University of Nebraska - Lincoln

2004

\title{
Natural and Technologic Hazardous Material Releases During and After Natural Disasters: A Review
}

\author{
Stacy Young \\ National Center for Environmental Health, Centers for Disease Control and Prevention, 1600 Clifton Road, \\ NE (Mailstop E-23), Atlanta, GA \\ Lina Balluz \\ National Center for Environmental Health, Centers for Disease Control and Prevention, 1600 Clifton Road, \\ NE (Mailstop E-23), Atlanta, GA \\ Josephine Malilay \\ National Center for Environmental Health, Centers for Disease Control and Prevention, 1600 Clifton Road, \\ NE (Mailstop E-23), Atlanta, GA
}

Follow this and additional works at: https://digitalcommons.unl.edu/publichealthresources

Part of the Public Health Commons

Young, Stacy; Balluz, Lina; and Malilay, Josephine, "Natural and Technologic Hazardous Material Releases During and After Natural Disasters: A Review" (2004). Public Health Resources. 90.

https://digitalcommons.unl.edu/publichealthresources/90

This Article is brought to you for free and open access by the Public Health Resources at DigitalCommons@University of Nebraska - Lincoln. It has been accepted for inclusion in Public Health Resources by an authorized administrator of DigitalCommons@University of Nebraska - Lincoln. 


\title{
Natural and technologic hazardous material releases during and after natural disasters: a review
}

\author{
Stacy Young*, Lina Balluz, Josephine Malilay \\ Health Studies Branch, Division of Environmental Hazards and Health Effects, National Center for Environmental Health, \\ Centers for Disease Control and Prevention, 1600 Clifton Road, NE (Mailstop E-23), Atlanta, GA 30333, USA
}

Received 12 April 2002; accepted 15 July 2003

\begin{abstract}
Natural disasters may be powerful and prominent mechanisms of direct and indirect hazardous material (hazmat) releases. Hazardous materials that are released as the result of a technologic malfunction precipitated by a natural event are referred to as natural-technologic or na-tech events. Na-tech events pose unique environmental and human hazards. Disaster-associated hazardous material releases are of concern, given increases in population density and accelerating industrial development in areas subject to natural disasters. These trends increase the probability of catastrophic future disasters and the potential for mass human exposure to hazardous materials released during disasters. This systematic review summarizes direct and indirect disaster-associated releases, as well as environmental contamination and adverse human health effects that have resulted from natural disaster-related hazmat incidents. Thorough examination of historic disaster-related hazmat releases can be used to identify future threats and improve mitigation and prevention efforts.
\end{abstract}

Keywords: Chemicals; Exposure; Health effects; Natural disasters; Na-tech

\section{Introduction}

Oil releases, agrochemical pollution, asbestos dust and aerosolized radionuclides may not be

\footnotetext{
Abbreviations: DDT, 1,1,1-trichloro-2,2-bis( $p$-chlorophenyl)ethane; Na-tech, natural-technologic; NMSZ, New Madrid Seismic Zone; PAH, polycyclic aromatic hydrocarbons; PCB, polychlorinated biphenyls; PCDD, polychlorinated dibenzo- $p$ dioxins; PCDF, polychlorinated dibenzofurans.

*Corresponding author. 6 Executive Park Drive, Building 6, Room 1036, Atlanta, GA 30329. Tel.: + 1-404-498-1455; fax: $+1-404-498-1355$.

E-mail address: say5@cdc.gov (S. Young).
}

hazards that immediately come to mind when considering types of damage associated with a natural disaster. Yet these threats are as real as those posed by rapidly moving floodwaters, damaged roadways or collapsing buildings. Hazardous materials (hazmats) released during extreme natural events (e.g. volcanic eruptions, earthquakes, landslides, hurricanes, tornadoes, blizzards) threaten human health by increasing the likelihood that individuals will be exposed to hazardous materials or to secondary hazards such as fires or explosions that result when flammable materials are ignited 


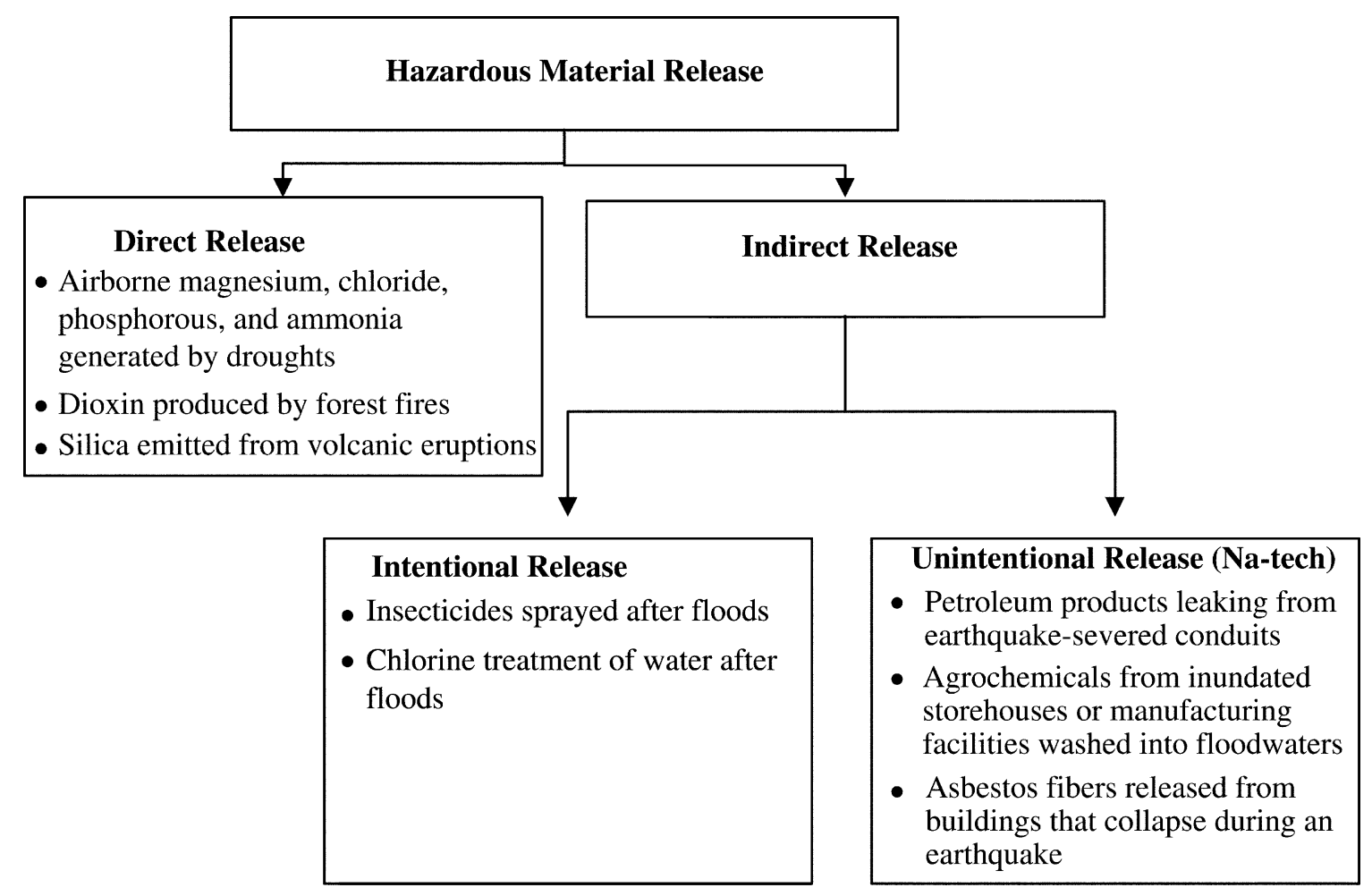

Fig. 1. Classification of hazardous material releases associated with natural disasters.

(Binder and Sanderson, 1987). This systematic review summarizes past incidents of chemical, radiologic and biologic releases associated with natural disasters and the adverse environmental and human health effects associated with these releases. Thorough examination of historic disaster-related hazmat releases can be used to identify future threats and improve mitigation and prevention efforts.

Natural disasters are geologic or meteorologic phenomena that precipitate a breakdown in the relation between humans and their environment or constitute a serious and sudden event (or a slow event, as in a drought) on such a scale that a stricken community requires extraordinary efforts to cope (Gunn, 1990; Wijkman and Timberlake, 1984; WHO, 1980). During the 1990s, natural disasters affected an annual average of 211 million people, were responsible for 666000 deaths and cost an estimated US \$79 billion per annum (2000 prices) (IFRC, 2001). The immediate morbidity, mortality and economic costs associated with natural disasters have been documented (OUSFDA, 1995; Mileti, 1999). However, the environmental consequences of such events have not been adequately studied.

A hazardous material is a substance that causes or contributes to an increase in injury, death or serious illness, or poses a substantial threat to humans or the environment because of its chemical, physical or infectious characteristics (ABAG, 1990). The hazard associated with a particular material is dependent upon its toxicity as well as the concentration and quantity that have been released. Natural disasters can be powerful and prominent mechanisms of direct and indirect hazardous material releases (Fig. 1). Direct releases of hazardous materials are generally consistent with the nature of an event, and few if any mitigating actions can be taken to prevent such 
releases. Conversely, indirect releases occur when technologic circumstances in combination with a natural event result in the discharge of a hazardous material into the environment. Indirect discharges can be further categorized into releases that are intentional or unintentional. Intentional discharges are made in an effort to thwart other more serious health threats. Unintentional releases are not planned and have no constructive purpose.

Unintentional hazardous material releases that result from technologic emergencies created by natural disasters have been referred to as naturaltechnologic or na-tech events (Showalter and Myers, 1994). Na-tech events represent a preventable source of environmental contamination associated with natural disasters because the technologic component of a na-tech event offers a point of intervention at which preventive action can be taken to ameliorate or eliminate the release of hazardous materials. Na-tech releases may be small: paints, solvents, insecticides and other household toxicants stored in home basements or garages and washed into floodwaters-or large: oil leaking from severed pipelines after an earthquake or radioactive aerosols formed by fires in polluted regions (White, 1993; Budyka and Ogorodnikov, 1995; Fields, 2000). Na-tech releases that occur on an industrial scale engender the greatest concern because they have the potential to result in mass human exposures and generally involve materials of greater toxicity.

Concerns about hazmat releases resulting from natural disasters have been raised recently because of increases in the number of natural disasters, as well as increases in population density in disasterprone areas and technologic and industrial expansion (Noji, 1997; IFRC, 2001; Wijkman and Timberlake, 1984). These phenomena increase the probability of catastrophic disasters and the potential for human exposure to hazardous agents released during disasters. A lack of standardized record keeping, however, has hampered efforts to assess the frequency and severity of hazmat occurrences during natural disasters. As a result, questions persist about possible discharges of hazardous materials after many natural disasters (White, 1993). The most pressing of these questions from a public health standpoint remains whether disas- ter-associated hazmat releases could potentially affect human health. Large-scale releases may pose serious water, soil and air contamination, as well as extreme fire and explosion threats that could translate into acute or chronic exposures and adverse health outcomes for people living near a disaster site (Sanderson, 1992). Chemical, radiologic and biologic releases during natural disasters have been documented by academic journals and national and local news sources (Tables 1 and 2). These reports suggest that natural disaster-associated hazmat releases may not be rare and that floods, earthquakes and volcanic eruptions probably present the greatest risk for actual and potential hazmat consequences (Sanderson, 1992).

\section{Flood- and wind-related storms}

\subsection{Historic hazmat incidents and future threats}

Floods are characterized by excessive, often unexpected, overflow of water into areas that are not normally submerged (Gunn, 1990). The greatest hazard associated with floods is rapidly moving and rising water. Strong winds, tornadoes, torrential rains, storm surges and hurricanes can exacerbate flood threats (Robinson, 1993). In some instances, hazardous materials may be intentionally discharged after floods and hurricanes. Communitywide pesticide spraying was considered during the 2-3 years after the Midwestern floods of 1993 (White, 1993; Anonymous, 1994) and conducted in counties in Florida and Louisiana after Hurricane Andrew to minimize threats of mosquitotransmitted diseases and secondary bacterial infections of mosquito bites (Anonymous, 1993). The Midwestern floods also prompted increases in the chlorine concentration of some Nebraska water supplies to counteract contamination from floodrelated line breaks (White, 1993). Reduction of vector-borne disease and decontamination of water supplies are examples of health benefits that accompany an intentional chemical release.

Unintentional hazmat releases also occur during flood- and wind-related storms. During the Midwestern floods, paints, solvents, insecticides and other household chemicals usually stored in home basements or garages were washed into flood- 


\section{Table 1}

Examples of direct releases of hazardous materials during and after natural disasters, as documented by academic journals and local or national news sources

\begin{tabular}{|c|c|c|c|c|}
\hline Natural event & Location, year & Nature of release & Human health effects ${ }^{\mathrm{a}}$ & Citation \\
\hline Drought & $\begin{array}{l}\text { Old Wives Lake, } \\
\text { Saskatchewan } \\
(1980 \text { s) }\end{array}$ & $\begin{array}{l}\text { Airborne sodium, sulfate, } \\
\text { magnesium, chloride, } \\
\text { phosphorous and ammonia }\end{array}$ & $\begin{array}{l}\text { Injuries: } \\
\text { (a) Increased prevalence of current cough, } \\
\text { current wheeze, chronic cough, chronic } \\
\text { wheeze, chronic eye irritation and chronic } \\
\text { nasal irritation }\end{array}$ & Gomez et al. (1992) \\
\hline Forest fires & $\begin{array}{l}\text { Malaysia and } \\
\text { Indonesia (1997) }\end{array}$ & $\begin{array}{l}\text { Ozone, nitrogen dioxide, } \\
\text { sulfur dioxide, carbon } \\
\text { monoxide and } \\
\text { particulate matter }\end{array}$ & $\begin{array}{l}\text { Injuries: } \\
\text { (a) } 8000 \text { hospital admissions for health } \\
\text { problems related to pollution }\end{array}$ & Swinbanks (1997) \\
\hline Forest fires & Canada (1980s) & Dioxin & Information not available & Gribble (1994) \\
\hline Forest fires & $\begin{array}{l}\text { California, US } \\
\text { (1987) }\end{array}$ & $\begin{array}{l}\text { Respirable particulates, } \\
\text { carbon monoxide, } \\
\text { nitrogen oxides and } \\
\text { hydrocarbons }\end{array}$ & $\begin{array}{l}\text { Injuries: } \\
\text { (a) Increases in hospital visits by persons } \\
\text { with asthma, chronic obstructive } \\
\text { pulmonary disease, sinusitis, upper } \\
\text { respiratory infections and laryngitis }\end{array}$ & Duclos et al. (1990) \\
\hline $\begin{array}{l}\text { Volcanic } \\
\text { eruption }\end{array}$ & $\begin{array}{l}\text { Lake Nyos, } \\
\text { Cameroon (1986) }\end{array}$ & Carbon dioxide & $\begin{array}{l}\text { Deaths: } \\
\text { (a) } 1700 \text { (asphyxiation) } \\
\text { Injuries: } \\
\text { (a) Cough, headaches, skin lesions, fever, } \\
\text { weakness, limb swelling, pulmonary } \\
\text { edema, conjunctivitis, joint pain and } \\
\text { cutaneous bullae }\end{array}$ & $\begin{array}{l}\text { Baxter et al. (1989) } \\
\text { Kerr (1989) }\end{array}$ \\
\hline $\begin{array}{l}\text { Volcanic } \\
\text { eruption }\end{array}$ & $\begin{array}{l}\text { Mount St. Helens, } \\
\text { US (1980) }\end{array}$ & $\begin{array}{l}\text { Particulate matter, } \\
\text { crystalline silica, radon, } \\
\text { sulfur dioxide, carbonyl } \\
\text { sulfide, carbon disulfide, } \\
\text { nitrogen dioxide, } \\
\text { chloromethane, carbon } \\
\text { dioxide, carbon } \\
\text { monoxide, nitrous oxide, } \\
\text { ethane and acetylene }\end{array}$ & $\begin{array}{l}\text { Deaths: } \\
\text { (a) } 18 \text { (asphyxiation) } \\
\text { Injuries: } \\
\text { (a) Fourfold increase in the number of } \\
\text { asthma patients } \\
\text { (b) Twofold increase in the number of } \\
\text { bronchitis patients } \\
\text { (c) Increased emergency department visits } \\
\text { for ocular foreign bodies, corneal } \\
\text { abrasions and conjunctivitis }\end{array}$ & $\begin{array}{l}\text { Baxter et al. (1981) } \\
\text { Eisele et al. (1981) } \\
\text { Nania and Bruya (1982) } \\
\text { Fraunfelder et al. (1983) } \\
\text { Olsen and Fruchter (1986) } \\
\text { Green et al. (1982) }\end{array}$ \\
\hline $\begin{array}{l}\text { Volcanic } \\
\text { eruption }\end{array}$ & $\begin{array}{l}\text { Hekla, Iceland } \\
(1947-1948 ; 1970)\end{array}$ & $\begin{array}{l}\text { Fluoride contamination } \\
\text { of soil and water }\end{array}$ & Information not available & $\begin{array}{l}\text { Sigurdsson and Palsson (1957) } \\
\text { Nania and Bruya (1982) and Georgsson and Peterson (1972) } \\
\text { Thórarinsson (1979) and Baxter et al. (1982) }\end{array}$ \\
\hline
\end{tabular}

\footnotetext{
${ }^{a}$ Absence of health effects does not necessarily indicate that no health effects were associated with a given release, only that no heath effects were reported by the cited source.
} 
Table 2

Examples of indirect, intentional and unintentional (na-tech) releases of hazardous materials during and after natural disasters as documented by academic journals and local or national news sources

\begin{tabular}{|c|c|c|c|c|c|}
\hline Releases & Natural event & Location, year & Nature of release & Human health effects ${ }^{\mathrm{a}}$ & Citation \\
\hline \multicolumn{6}{|c|}{ Intentional } \\
\hline & Hurricane & Florida and Louisiana, & Mosquito-control insecticides & Information not available & Anonymous (1993) \\
\hline & Andrew & US (1993) & Chlorine disinfectant & Information not available & White (1993) \\
\hline
\end{tabular}

Unintentional

(Na-tech)

Earthquake

Earthquake

Turkey (2000)

Kobe City, Japan

(1995)

Earthquake

Northridge, California US (1994)

Earthquake

Northern California, US (1989)

Earthquake

Whittier Narrows, CA US (1987) breaks where dirt had mixed

with water in the pipe

9 petroleum pipeline ruptures totaling $8705501 ; 752$ natural gas line breaks; 60 emergency hazmat incidents including a 75701 release of sulfuric acid during a train derailment

300-400 natural gas line breaks; and 300 hazmat releases involving miscellaneous toxicants (e.g. cleaners, insecticides, sodium hydroxide, asbestos dust, fiberglass

insulation, mercury, cyanide, ammonia, hydrochloric acid, natural gas, smoke, carbon monoxide), the largest being a 5000-2000 pound release of ammonia from a food processing plant

1411 natural gas line breaks and 30 hazmat releases including the release of $2 / 3$ of the contents of a 1-ton chlorine cylinder
Information not available

Deaths:

(a) Three (attributed to

exacerbation of asthma

by dust)

Injuries:

(a) Exacerbation of

asthma symptoms

Information not available

Lindell and Perry (1997)

Lindell and Perry (1998)

Injuries:

(a) $20 \%$ of after-

earthquake, work-related

injuries attributed to

hazmats

(b) 12 calls to regiona

poison control centers

Durkin et al. (1991)

Nathan et al. (1992)

Lindell and Perry (1996a)

Lindell and Perry (1996b)

Information not available

Lindell and Perry (1996a) Lindell and Perry (1996b) 


\begin{tabular}{|c|c|c|c|c|c|}
\hline Releases & Natural event & Location, year & Nature of release & Human health effects ${ }^{\mathrm{a}}$ & Citation \\
\hline & Earthquake & $\begin{array}{l}\text { Mexico City, Mexico } \\
\text { (1985) }\end{array}$ & $\begin{array}{l}\text { Natural gas and sulfurous odors } \\
\text { from leaking gasoline storage } \\
\text { tanks }\end{array}$ & Information not available & $\begin{array}{l}\text { Anderson et al. (1985) } \\
\text { Boraiko (1986) }\end{array}$ \\
\hline & Earthquake & $\begin{array}{l}\text { Miyagi-ken-oki, Japan } \\
\text { (1978) }\end{array}$ & $\begin{array}{l}68 \text { million } 1 \text { of heavy oil } \\
\text { released, } .9 \text { million of which } \\
\text { flowed into storm drains and } \\
\text { into waterways }\end{array}$ & Information not available & Selvaduray (1986a) \\
\hline & Floods & $\begin{array}{l}\text { River Meuse, } \\
\text { Netherlands, France } \\
\text { and Belgium (1993, } \\
\text { 1995) }\end{array}$ & $\begin{array}{l}\text { Cadmium, zinc, lead, copper, } \\
\text { pesticides and PAHs }\end{array}$ & Information not available & Albering et al. (1999) \\
\hline & Floods & Midwest, US (1993) & $\begin{array}{l}22 \text { Superfund sites possibly } \\
\text { containing toxicants such as } \\
\text { benzene, toluene, lead and } \\
\text { chromium; small amounts of } \\
\text { paints, solvents, insecticides and } \\
\text { other household toxicants; and } \\
\text { lead paint flaking from building } \\
\text { materials such as drywall or } \\
\text { woodwork }\end{array}$ & Information not available & White (1993) \\
\hline & Floods & $\begin{array}{l}\text { Southeastern Idaho, } \\
\text { US (1976) }\end{array}$ & $\begin{array}{l}\text { At least } 2000 \text { pounds of } \\
\text { granular Di-Syston }{ }^{\circledR} \text { and } 200 \\
\text { gallons of liquid Furadan }{ }^{\circledR} \text { in } \\
\text { addition to unknown quantities } \\
\text { of DDT, PCBs, Guthion }{ }^{\circledR} \text {, } \\
\text { Dinitro }{ }^{\circledR}, 2,4-D \text {, Thimet }{ }^{\circledR} \text {, } \\
\text { Systox }{ }^{\circledR} \text { and malathion }{ }^{\mathrm{b}} \text { released } \\
\text { from three commercial facilities } \\
\text { and storehouses on farms }\end{array}$ & $\begin{array}{l}\text { Injuries: } \\
\text { (a) PCB and DDT levels } \\
\text { high in area fish- } \\
\text { approaching } 2000 \mu \mathrm{g} / \mathrm{kg} \text {. } \\
\text { No human health hazards } \\
\text { were apparent during the } \\
1979 \text { study }\end{array}$ & Perry (1979) \\
\hline & Hurricane Floyd & $\begin{array}{l}\text { Raritan River, New } \\
\text { Jersey, US (1999) }\end{array}$ & $\begin{array}{l}500 \text { barrels-including oil } \\
\text { drums fromgas stations, } \\
\text { containers from chemical } \\
\text { companies, household paint } \\
\text { containers and propane } \\
\text { cylinders }\end{array}$ & Information not available & Picard (1999) \\
\hline & Hurricane Floyd & $\begin{array}{l}\text { Eastern North Carolina, } \\
\text { US (1999) }\end{array}$ & $\begin{array}{l}\text { Fuel oil and propane tanks; } \\
\text { contents of } 50 \text { hog waste } \\
\text { lagoons (many several acres in } \\
\text { size) and } 20 \text { municipal waste- } \\
\text { treatment plants that were } \\
\text { inundated by flood waters }\end{array}$ & Information not available & $\begin{array}{l}\text { Schmidt }(2000) \\
\text { Bowie }(2000)\end{array}$ \\
\hline
\end{tabular}


Table 2 (Continued)

\begin{tabular}{|c|c|c|c|c|c|}
\hline Releases & Natural event & Location, year & Nature of release & Human health effects ${ }^{\mathrm{a}}$ & Citation \\
\hline & $\begin{array}{l}\text { Hurricane } \\
\text { Mitch }\end{array}$ & $\begin{array}{l}\text { Barrio of Istoca, } \\
\text { Honduras (1998) }\end{array}$ & $\begin{array}{l}300-400 \text { barrels of pesticides } \\
\text { and chemicals including toluene } \\
\text { and endosulfan }\end{array}$ & Information not available & Balluz et al. (2001) \\
\hline & Severe storms & Coast of France (1993) & $\begin{array}{l}88 \text { containers of Apron Plus DS } \\
\text { (metalaxyl), a fungicide, and } \\
\text { other chemicals }\end{array}$ & Information not available & $\begin{array}{l}\text { PANNA (2003) } \\
\text { Simons (1993) }\end{array}$ \\
\hline & Landslides & $\begin{array}{l}\text { Northridge, CA, US } \\
\text { (1994) }\end{array}$ & $\begin{array}{l}\text { Airborne arthrospores dislodged } \\
\text { from soil }\end{array}$ & $\begin{array}{l}\text { Deaths: } \\
\text { (a) } 3 \text { fatalities } \\
\text { Injuries: } \\
\text { (b) } 200 \text { non-fatal } \\
\text { outbreak-associated } \\
\text { coccidioidomycosis cases }\end{array}$ & Schneider et al. (1997) \\
\hline \multicolumn{6}{|c|}{ 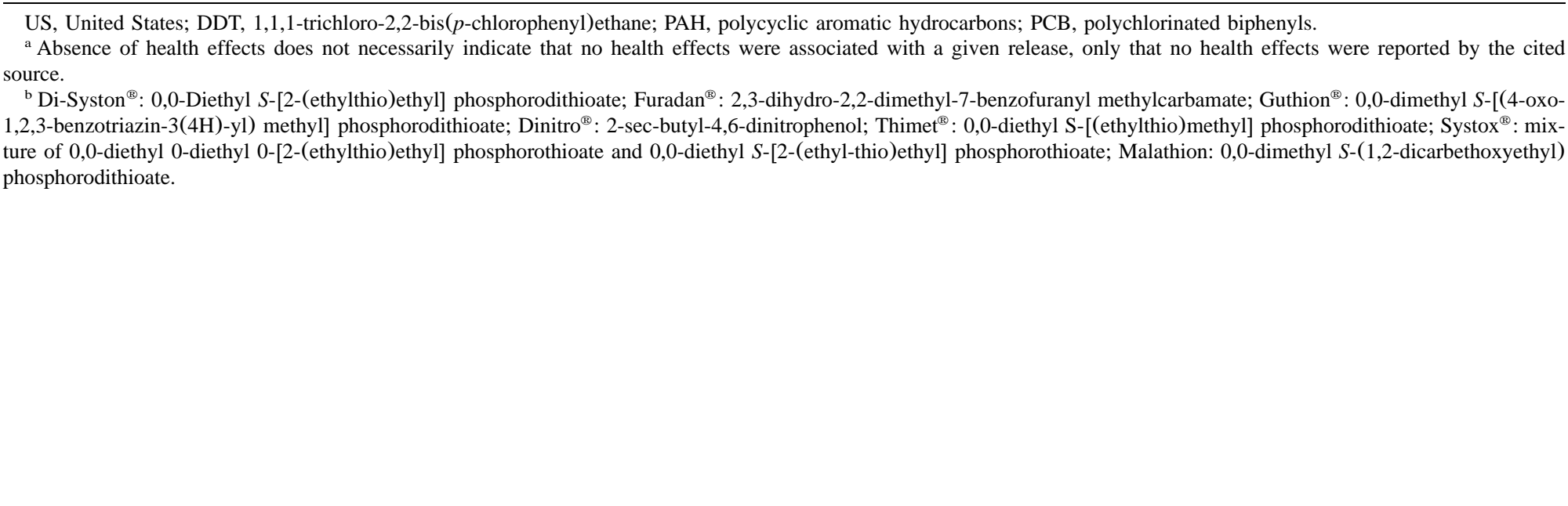 } \\
\hline
\end{tabular}


exact depthbegin articleMp 7 page 7 frame 4 waters, and lead paint flaked from drywall and woodwork in houses that had been inundated (White, 1993). Cylinders containing flammable propane were found in waterways after Hurricane Floyd and posed an explosive threat to boaters (Picard, 1999). Of greatest concern, however, are large-scale unintentional, na-tech releases from industrial, Superfund and agricultural sites located near streams, rivers or coastlines. Rising floodwaters and high winds can uproot petroleum tanks, rupture underground oil or gasoline pipelines, dislodge storage tanks, liberate chemicals stored at ground level and disrupt water purification and sewage disposal systems (Noji, 1991). Approximately 500 barrels of various sizes and descriptions-including oil drums from gas stations and containers from chemical companies-were pulled from the Raritan River (New Jersey) or discovered on shore after Hurricane Floyd (Picard, 1999). Heavy rains in Vila Parisi, Brazil, during 1995 resulted in a major discharge when floods caused a pipe break at a fertilizer plant and resulted in the release of a huge ammonia cloud over a nearby town (WBG, 2000). Hazardous materials used in industrial and agricultural processes conducted in the catchment area near the River Meuse (one of the major rivers in Europe) were dispersed when the river flooded and riverbanks were overwhelmed. Regular inundation eventually led to the contamination of water and soil by heavy metals including zinc, lead and cadmium, as well as multiple organic compounds such as pesticides and polycyclic aromatic hydrocarbons (PAH) (Albering et al., 1999).

Waste can overflow and buried waste can be exposed when floods or windstorms strike sites where hazardous waste is stored (Noji, 1991). Landfills and 22 Superfund sites-possibly containing toxicants such as benzene, toluene, lead and chromium-may have been affected during the Midwest floods in 1993 (White, 1993; Fields, 2000). Hundreds of thousands of gallons of biologic waste polluted North Carolina waterways when Hurricane Floyd struck farms in low-lying areas and flooded waste lagoons and municipal waste-treatment plants. One of the largest releases was from a chemical plant that deposited 1 million gallons of wastewater containing at least 50 pounds of chromium into the Cape Fear River (Bowie, 2000; Schmidt, 2000).

Agrochemicals can be flushed into residential districts and rivers when agricultural areas are submerged (Malilay, 1997). At least three commercial facilities and many farm storehouses were damaged when the Teton Dam in Southeastern Idaho collapsed. The resulting flooding triggered the release of 2000 pounds of organophosphate pesticides, 200 gallons of carbamates and unknown quantities of 1,1,1-trichloro-2,2-bis ( $p$-chlorophenyl)ethane (DDT), polychlorinated biphenyls (PCB) and other chlorinated compounds into the Snake River (Perry, 1979). Three hundred to 400 barrels of pesticides and chemicals, including toluene and endosulfan, were released in the barrio of Istoca, Department of Choluteca, Honduras, after Hurricane Mitch. Soil levels of chlopyrifos and parathion measured after the hurricane were 30 and 1000 times higher, respectively, than environmental data quality levels (Balluz et al., 2001).

Flood-related breaks in distribution lines that allow contaminated dirt and water to mix with water in pipes could pose a unique problem in the event of runoff from pesticide-laced fields or the destruction of pesticide manufacturing and storage facilities. Flooding may also affect the persistence of chemicals-in particular some pesticidesheightening the potential for chronic exposures. The uptake of pesticides such as aldrin and herbicides such as molinate is enhanced in rice plants and grains in flooded soils and the pesticides persist longer in these plants than in those found in nonflooded soils (Singh et al., 1985; Thomas and Holt, 1980).

\subsection{Health effects associated with flood- and wind-related hazmat releases}

Human health can be adversely affected when acute or chronic exposures to hazardous materials occur as a result of floods or hurricanes. Stress and respiratory problems were reported following the breach of waste lagoons in North Carolina after Hurricane Floyd (Schmidt, 2000). In Brazil, many residents were injured and a mass evacuation occurred after the flood-related release of an 
ammonia cloud from an industrial site (WBG, 2000). Increased leukemia and lymphoma rates may have been related to a transient environmental contamination factor associated with flooding in western New York during 1972. Rates of these cancers in river valleys that were flooded when Tropical Storm Agnes struck were 35\% higher than would be expected and significantly different than rates in areas not affected by flooding (Janerich et al., 1981). Fires that result when flammable gases or liquids are released and ignited pose an additional threat to human health. A substantial number of casualties in floods can be accounted for by fires that resulted when oil and gasoline storage tanks were severed and the resultant film on the water surface was ignited (e.g. by watercraft) and spread (Orlowskii, 1988).

\section{Earthquakes}

\subsection{Historic hazmat incidents and future threats}

Earthquakes are characterized by violent shaking of the ground produced by deep seismic waves with hazards that include ground trembling, soil liquefaction and tsunamis (Gunn, 1990; Noji, 1997). Highly industrialized earthquake-prone areas such as those in Northern California risk the release of hazardous liquid (e.g. sodium hydroxide; acetone; freon; xylene; tricloroethane; trichloroethylene; sulfuric, nitric, hydrochloric and hydrofluoric acid) and gaseous (e.g. arsine, phosphine, chlorine, ammonia, hydrogen chloride and silane) materials (Werner et al., 1989). Quakes in areas where these materials are used or stored could lead to the formation of gas clouds; runoff of liquids to creeks or storm drains; and releases onto soil, with subsequent threats to surface and groundwater resources (Werner et al., 1989; Stratton, 1989).

The Whittier Narrows quake in October 1987 (Richter magnitude of 5.9) occasioned at least two significant hazardous material incidents: the release of $2 / 3$ of the contents of a 1-ton chlorine cylinder at a facility in Santa Fe Springs and several chemical spills, a major fire and subsequent asbestos contamination at California State University, Los Angeles (Tierney, 1989). The fire resulted when a 1-gallon container storing sodium metal tipped over during the quake. Water leaking from a safety shower that had ruptured as a result of the shaking reacted with the sodium to produce hydrogen gas that ignited and spread, vaporizing mercury and exposing asbestos (Lindell and Perry, 1996a).

Hazardous releases were reported from approximately 200 laboratories (e.g. university, hospital, pharmaceutical and high school), 100 industrial facilities (e.g. food processing and packaging plants, metal plating facilities, gas stations, airports and farms) and numerous shops (e.g. drug stores, hair salons and restaurants) and private residences after the Loma Prieta quake in California during 1989. The incidents included acid, solvent, pesticide, fertilizer and petroleum product releases. Three of the largest releases associated with the 7.1 magnitude Loma Prieta quake were 50000 gallons of aqueous solution released from a semiconductor facility, between 5000 and 20000 pounds of ammonia released from a food processing plant and 15000 yard $^{3}$ of fuel released from underground storage containers. At least 57 buildings were reported to have asbestos contamination (ABAG, 1990).

The Northridge earthquake (Richter magnitude of 6.7) in 1994 produced hazmat incidents at 134 locations. Many releases were from breached oil pipelines that contaminated soil and ground water. Other incidents included a train derailment that resulted in the release of 75701 of sulfuric acid, multiple releases at aerospace industrial facilities and fires and hazmat releases at California State University science laboratories (Lindell and Perry, 1996a). Post-incident inspections conducted by the Los Angeles County Fire Department revealed that hazmat releases occurred in 5\% of the commercial facilities and $20 \%$ of the industrial facilities in the high impact area (Lindell and Perry, 1998). Hazmat incidents, however, were not limited to the high impact area. Two oil refineries $65 \mathrm{~km}$ from the epicenter, in an area of moderate intensity, also reported releases (Lindell and Perry, 1998).

The release of flammable gases or liquids (e.g. petroleum products) during earthquakes is of particular concern. In addition to the contamination threat posed by the release of flammables, extreme fire, explosive and inhalation hazards can result 
when these materials ignite (Werner et al., 1989; Stratton, 1989). Geologists, structural engineers and architects theorize that a sizeable quake in the San Francisco Bay Area of California would result in fires in the streets caused by broken gas mains, and structural fires from broken service connections. Six major refineries in the San Francisco Bay Area are subject to shaking and damage from ground failure and all major pipelines transporting petroleum fuels to the Bay Area cross the Hayward fault and are vulnerable to damage by surface fault rupture (Steinbrugge et al., 1986). Petroleum, natural gas, water and sewage pipelines in the New Madrid Seismic Zone in the central Mississippi Valley are also vulnerable to high levels of seismic activity (SLUEC, 2003; Noji, 1989). Future quakes in this area could precipitate a major release given that nearly 1 million barrels of crude oil are delivered daily from wells in the Gulf of Mexico to refineries in the Midwest though a 40-inch diameter pipeline that travels 635 miles dangerously close to a fault line (Nyman et al., 1993).

Devastating petroleum releases have occurred in past earthquakes. The 1964 Niigata earthquake in Japan resulted in major releases that led to fires that burned for more than 14 days and consumed 154 million liters of petroleum products (Selvaduray, 1986a). During the 1978 Miyagi-ken-oki earthquake, 68 million liters of heavy oil were released, 2.9 million liters of which drained into waterways despite mitigation efforts (Selvaduray, 1986a). Petroleum pipeline releases during the Northridge earthquake totaled 400000 gallons, some (173000 gallons) of which combined with releases from broken waterlines and flowed into storm drains contaminating 12 miles of river for more than 6 weeks (Lindell and Perry, 1996b). California Gas reported 35 breaks in natural gas transmission lines and 717 breaks in distribution lines following the Northridge quake (Lindell and Perry, 1996b). Leaking fuel tanks and the rupture of underground gas and oil lines resulted in fires during seismic events in Mexico City in 1985 and Kobe, Japan, in 1995 (Baba et al., 1996; Boraiko, 1986; EQE International, 1985). A major refinery fire threatened the health and safety of victims following a 1999 quake in Turkey (Fields, 2000).

\subsection{Health effects associated with earthquake- related hazmat releases}

Escaping gases, chemicals, heavy dust and fires pose serious threats to rescuers, clean-up personnel and occupants trapped in buildings and can impact earthquake-related morbidity and mortality (Stratton, 1989). Multiple exposures to hazmats (e.g. asbestos and fiberglass insulation, mercury, cyanide, hydrochloric acid, carbon monoxide, transformer fluid) were reported to regional poison control centers after the Loma Prieta earthquake (Nathan et al., 1992). Additionally, after the Loma Prieta quake, California Department of Industrial Relations records indicated that nearly $20 \%$ of after-earthquake, work-related injuries were caused by hazardous materials. Victims were predominately security and maintenance personnel and managers who were exposed (e.g. inhaled dust or chemical fumes, slipped on spilled chemicals and suffered burns and blisters) while searching buildings, directing evacuations or participating in clean-up operations (Durkin et al., 1991). During the clean-up period after the Kobe quake, rescue and demolition workers without access to personal protective equipment were exposed to asbestoscontaining dust containing crocidolite concentrations that exceeded international occupational exposure limits (Nukushina, 1995; NIOSH, 2003). Oil releases prompted by the Niigata earthquake resulted in fires that spread from industrial sites to surrounding residential areas, consuming private homes and affecting 1375 people (Selvaduray, 1986a).

\section{Volcanic eruptions}

\subsection{Historic hazmat incidents and future threats}

Carbon dioxide, hydrogen sulfide, hydrogen fluoride, carbon monoxide, radon, silica and halogenated hydrocarbons are directly released during volcanic events (Baxter et al., 1990; Bernstein et al., 1986). Gases and other volatile materials can be washed onto crops or into watercourses (Baxter, 1989) where they can become worked into topsoil and lower the acidity of rivers-endangering fish and affecting drinking water (Buist et al., 1986b; 
Baxter, 1997). Silica and radioactive radon daughters that are scavenged from the air by falling ash can be easily inhaled and can lodge in the respiratory tract (Baxter et al., 1982; Olsen and Fruchter, 1986).

Ash generated by volcanic eruptions also can disrupt sewage and water treatment, damage machinery and electronic equipment, cause electricity outages and alter road conditions. Technologic malfunctions such as these could result in hazardous releases. Sewage-treatment plants may be put out of action when heavy ashfalls overwhelm filter beds and abrasive ash damages machinery. As a result, raw sewage may be diverted to surface waters (Baxter et al., 1986). Tremendous amounts of ash threatened mechanical equipment in Spokane's sewage treatment facility during the Mount St. Helens eruption. As a result, treatment levels were reduced from secondary to primary (US EPA, 1980). Reduction or interruption of water treatment caused by a technologic malfunction precipitated by a natural disaster could lead to contamination of water supplies and represents a unique form of na-tech release. Transport of hazardous cargo on slippery, ash-covered roads could also lead to collisions and contamination of areas around a collision site (Baxter et al., 1982).

\subsection{Health effects associated with volcanic-related hazmat releases}

Hazardous releases associated with lava flows, hot gases and ash could potentially result in acute exposures and a variety of immediate and longterm health effects. Volcanic ash may cause severe tracheal injury, pulmonary edema and bronchial obstruction at high concentrations-leading to death from acute pulmonary injury or suffocation (Eisele et al., 1981; Manni et al., 1988). Deaths from hydrogen sulfide and carbon monoxide have been documented in Cameroon, Japan and Iceland (Kawari et al., 1978; Thórarinsson, 1979).

Upper and lower airway inflammation, decreased lung capacity, cough and bronchospasm as well as exacerbation of chronic lung diseases are common findings in symptomatic patients near active volcanic sites (Buist et al., 1986a; Baxter, 1989; Baxter et al., 1982; Bernstein et al., 1986).
Increases were observed in the number of asthma and bronchitis patients who sought emergency medical care at major hospitals in areas of ashfall after the Mount St. Helens eruption (Baxter et al., 1982). The number of admissions to the pediatric ward increased during the first week of volcanic activity in St. Vincent, West Indies (Leus et al., 1981). Volcanic emissions also may irritate the eyes (e.g. ocular foreign bodies, corneal abrasions and irritant conjunctivitis) and mucous membranes (Buist et al., 1986a; Fraunfelder et al., 1983) and cause joint pain, muscle weakness, connective tissue disorders and cutaneous bullae (Baxter et al., 1982, 1989; Bernstein et al., 1986).

\section{Wildfires, droughts and other disasters}

\subsection{Historic hazmat incidents and future threats}

Other natural events-including wildfires, droughts, mudslides, tsunamis and severe thunderstorms-may also contribute to the release of hazardous materials into the environment. Biomass burning can produce carbon monoxide, aldehydes, organic acids, semivolatile and volatile organic compounds, free radicals and ozone (Levine, 1999; Ward, 1997; Breysse, 1984). Many of these compounds consist of irritant respirable particles and gases that in some cases may be carcinogenic (Ward, 1989). Of particular concern are the organochlorine compounds-including polychlorinated dioxins (PCDD) and polychlorinated dibenzofurans (PCDF) - that can be found in smoke from burning wood. Forest fires and brush fires are major sources of PCDD-including 2,3,7,8tetrachlordibenzo- $p$-dioxin (Gribble, 1994). Wildfires encroaching upon polluted regions may also redistribute contaminants from areas where they posed relatively low exposure hazards to areas where human exposure is more likely to occur. In 1992, wildfires in the Gomel Region of Belarus spread into the $30-\mathrm{km}$ radius zone of the Chernobyl Power Plant. The fires lifted ${ }^{137} \mathrm{Cs}$ radionuclides that had been previously concentrated in the forest litter and upper mineral layer of the soil into the atmosphere resulting in a 10-fold increase in the level of radioactive cesium in aerosols (Schwela et al., 1999; Budyka and Ogorodnikov, 1995). 
Drought, severe storms and landslides have also triggered hazardous releases. Water diversions and drought during the late 1980s resulted in the evaporation of Old Wives Lake in Saskatchewan, Canada. Desiccation and prevailing northwest winds generated large quantities of airborne silt and clay containing sodium, magnesium, sulfate, chloride, phosphorous and ammonia (Gomez et al., 1992). Fungus growths can be spread in dust clouds generated by landslides or dust storms (Galgiani, 1999). Severe thunderstorms played a role in the release of 88 chemical containers from a freighter carrying a cargo of pesticides and other hazardous materials. As a result, packages containing hazardous materials were released into waters off the coast of France and debris washed onto beaches from Belgium to Spain (PANNA, 2003; Simons, 1993).

\subsection{Health effects associated with other natural disaster-related hazmat releases}

Biomass combustion products have been associated with impaired lung function; increases in respiratory and cardiovascular mortality and morbidity; increased cancer incidence; skin, eye and mucous membrane irritation; drowsiness; nausea; coughing, wheezing and shortness of breath; impaired judgment and death (Breysse, 1984). Smoke containing hazardous levels of ozone, nitrogen dioxide, sulfur dioxide, carbon dioxide and particulate matter resulted in at least 8000 hospital admissions in Malaysia during the 1997 Indonesian forest fires (Swinbanks, 1997). Hospital emergency department visits of persons with asthma and chronic obstructive pulmonary disease significantly increased during the major forest fire activity in California during 1987. Visits of persons with sinusitis, upper respiratory infections and laryngitis also were higher than expected in the six counties most severely affected by smoke or fire (Duclos et al., 1990). Fatalities resulting from excessive carbon monoxide concentrations alone or in combination with other pollutants were reported during forest fires in China (1987), Australia (1983) and Côte d'Ivoire (1982-1983) (Schwela et al., 1999). The health effects of chronic exposure to haze (e.g. from July to October each year in areas with annual burning trends) are unknown (Beardsley, 1997).

Severe drought may also result in exposures that can have detrimental effects on health. Respiratory symptoms (e.g. coughing, wheezing, nasal irritation) that show strong associations with sodium, magnesium, sulfate, chloride and other toxicant levels have increased in prevalence near desiccated Old Wives Lake in Saskatchewan, Canada (Gomez et al., 1992). Two hundred outbreak-associated cases of coccidioidomycosis, also known as Valley Fever, occurred in Ventura County, California, after individuals inhaled airborne arthospores that were dislodged from the soil during landslides that occurred in 1994 (Schneider et al., 1997).

\section{Discussion}

Disaster-related hazardous material releases are not uncommon events, but are tangible threats with the potential to adversely affect human health. Our review of historic disaster-related hazmat releases illustrates (1) the types of releases that are likely to occur during different natural disasters and (2) how human health can be affected through direct exposure to hazardous materials or to fires and explosions that result when flammable gases or liquids are ignited. Our review, however, includes only those events that have been documented by academic journals or national and local news reports. Many disaster-related hazardous material releases never receive such attention, in part, because public authorities, the media and the public generally overlook hazmat releases in the rush to address and recover from immediate disaster threats (Breslin, 1993). Limited research funding and the incentive that responsible parties have to suppress publicity for their releases further contribute to the lack of documentation and underreporting of disaster-related hazardous material releases. Consequently, the magnitude of the threat posed by hazardous material releases in disaster circumstances has probably been underestimated.

Public health impacts from disaster-associated hazmat exposures are also rarely documented and potentially underestimated (Sanderson, 1992). Studies that have looked for associations between disaster-related hazardous material releases and 
health are rare and complicated. Since many hazmat releases go unrecognized, it can be difficult to identify associated health effects (Breslin, 1993). Symptoms associated with hazmat exposures are often subtle or nonspecific and may have a latency effect (French and Holt, 1989). Longterm health effects associated with disaster-related hazardous material releases have been hypothesized but are particularly difficult to identify and confirm (Kung et al., 1981; Ziegler, 1993).

What is clear from historic accounts is that disaster-related hazardous material releases can affect large geographic areas and large numbers of people. Containers lost in the Raritan River after Hurricane Floyd were reported on Staten Island, New York, and on the beaches of Monmouth and Ocean counties in New Jersey (Picard, 1999). Chemical containers lost off the coast of France during a storm were recovered in Belgium, the Netherlands and Germany (PANNA, 2003; Simons, 1993). Smoke pollution from Indonesian wildfires spread as far as Kuala Lumpur on the west side of the Malay peninsula and rose to unhealthy levels in Singapore (Swinbanks, 1997), where outpatient attendance for haze-related conditions such as upper respiratory tract illness and asthma increased by 30\% (Emmanuel, 2000).

The scope of disaster-associated hazardous material releases is alarming given the increased potential for future events, in particular unintentional, na-tech releases. A survey of emergency management agencies identified an increase in the number of na-tech events during the 1980s-with Hurricane Hugo and the Loma Prieta earthquake accounting for nearly 200 na-tech events (Showalter and Myers, 1994). Na-tech releases probably continued to increase throughout the 1990s (Binder and Sanderson, 1987). Future natural disasters will probably be accompanied by na-tech disasters as industries that use hazardous materials amass in areas subject to natural disasters (Tierney, 1989). Subsequent increases in population density in the same locations heighten the potential for human exposure and adverse health outcomes related to disaster-related hazardous material releases (Hagman, 1984; Wijkman and Timberlake, 1984).

Hazmat releases that occur as a direct result of the event may be difficult, if not impossible, to control. Many na-tech releases result from poor storage facilities, inadequate building structure and insufficient safety measures or emergency planning. The degree of na-tech threat depends on the susceptibility of individual facilities and their contents to damage during natural disasters. Examination of historic incidents can provide a framework for evaluating potential threats, assessing current and future prevention and mitigation approaches and developing improved strategies.

Land use planning to avoid hazard zones (e.g. 100-year flood plains, fault lines) should be used when locating landfills, Superfund sites, waste lagoons and industrial facilities. Implementing risk-reduction strategies in new buildings, retrofitting weak edifices and using special designs for tanks and pipeline supports can improve structures' ability to withstand the forces of a disaster (Selvaduray, 1986a). Petroleum releases that occurred during the Northridge earthquake and ammonia releases caused by flooding in Brazil might have been prevented had structures been relocated or better equipped to deal with the impact of ground shaking or heavy flooding, respectively. Industrial facilities and nuclear power stations that have been specially designed to withstand natural disasters have performed well (Whitman, 1986). Incorporating structural elements with proven effectiveness into a standard set of code provisions governing the design of structures that house or transport hazardous materials in areas subject to natural disasters could lessen the threat of future na-tech releases. In addition to structural recommendations, risk assessments in California have identified safety measures (e.g. specially designed shelving systems or containers; braces, anchors and straps on equipment; precautions for storage and transport of hazardous materials) to reduce nonstructural and secondary damage (ABAG, 1990). In Japan, technological developments (e.g. non-sparking electrical equipment, shutoff valves, layout of plant and equipment to minimize spread of disasters) are used to minimize risk of earthquake-associated releases (Selvaduray, 1986b).

Providing adequate information and skills to people most likely to be exposed to or in contact with hazardous materials during or after natural disasters (e.g. emergency response and medical 
personnel and security and maintenance personnel) is another important safety precaution. Personnel should be prepared for dealing with disaster-associated releases where breakdowns in utilities, malfunctions of control or alarm systems, shortages of emergency personnel and disruption of transportation systems can complicate responses (ABAG, 1990). Raising private and municipal awareness of the environmental hazards associated with natural disasters is also important. In Japan, industries have implemented disaster prevention education by a variety of means including lecturers, distribution of pamphlets, posters and exercises at regular intervals (Selvaduray, 1986a). Public announcements before the 1993 Midwestern floods instructed farmers to move their tanks of anhydrous ammonia to higher ground, homeowners to secure their propane containers and industries near rising waterways to remove hazardous materials and seal their plants (White, 1993).

Relevant controls, practices and institutions that are already a part of every community's governance mechanisms can be adapted to the management of disaster-related hazmat releases (Lindell and Perry, 1996b). In the US, regulations aimed at reducing hazmat problems stemming from normal manufacturing, use, transportation and disposal processes (e.g. Clean Water Act, Clean Air Act, Oil Pollution Act, Comprehensive Environmental Response and Compensation Liability Act) can be adjusted to consider the specific hazmat threats posed by natural disasters (Lindell and Perry, 1996a). Areas at high risk of natural disasters can adopt more stringent standards than those mandated by the state or federal governments for facilities handling hazardous materials. For example, storage or handling of hazardous materials above a threshold quantity could be prohibited in seismically vulnerable buildings such as un-reinforced masonry buildings, or in areas subject to heavy flooding (ABAG, 1990).

Emergency response and public health assessment models also exist. Under The Emergency Planning and Community Right-to-Know Act of 1986, Local Emergency Planning Committees (LEPC) are required to develop an emergency response plan for reacting to a chemical accident. LEPC plans identify facilities and transportation routes of extremely hazardous substances, describe emergency response procedures, outline emergency notification procedures and detail methods for determining the occurrence of a release and the affected area and population (US EPA, 1993). The same elements are crucial in assessing vulnerability to disaster-related hazmat releases. Similarly, established methods for assessing environmental public health implications (e.g. ATSDR Public Health Assessment Guidance Manual) can be used to examine the impact of hazmat threats in natural disasters (ATSDR, 2003).

Cooperation is needed among government agencies, industry groups and researchers in order to more accurately assess the risk of disaster-related hazardous material releases and to promote the adoption of appropriate mitigation and prevention approaches (Lindell and Perry, 1998). In Japan, companies located in industrial zones have mutual aid agreements with other companies located in the same zone, sponsoring zone-wide emergency preparedness committees and preparedness exercises that involve member companies and public agencies (Selvaduray, 1986a). The Arizona Council for Earthquake Safety (ACES), composed of government and private sector representatives, has demonstrated how partnerships can be used to develop effective information dissemination, legislation and technical assistance strategies (Lindell and Perry, 1996b). The ACES developed plans for communicating disaster-related hazmat risks to businesses, noting how incentives for positive future actions (e.g. rewarding seismic designs for new structures) are more successful in dealing with low probability-high consequence dangers than penalties for past actions (e.g. requiring retrofits to old construction) and emphasizing the positive business consequences of seismic safety (e.g. ensuring competitiveness, reducing losses). In Japan, damage information is disseminated so that other facilities, even if they have not suffered damage, can take countermeasures so that they will not suffer the same damage (Selvaduray, 1986a). Information exchanges like these make decisions makers aware of threats and preparedness actions that can manage vulnerability (Lindell and Perry, 1996b). 


\section{Conclusion}

Anecdotal accounts of hazmat releases during natural disasters can be used to generate hypotheses about the incidence of disaster-related releases and to identify mitigation and preparedness measures. However, regional assessments and systematic studies of events that provide information on incidence and types of events are essential for determining the extent of disaster-associated hazmat releases, evaluating the efficacy of preparedness and mitigation measures, and enhancing subsequent strategies.

Vulnerability assessments can help estimate the proportion of fixed-site facilities and transportation routes in high probable-damage areas that are likely to experience releases, the magnitude of those releases, the potential casualties and the social disruption and economic losses resulting from such releases (Lindell and Perry, 1996a). Damage assessments following a disaster can provide important information for restructuring responses and investigating relationships between hazmat incidence and characteristics such as disaster intensity, mitigation measures and facility type. Damage assessments provided by the Los Angeles County Fire Department Health and Hazardous Materials Division following the Northridge earthquake highlighted fixed-site facilities with the greatest potential for acute health hazards (e.g. plating facilities or manufacturing facilities with large open top tanks containing chemical solutions; retail pool supply stores; and school, university, hospital and independent medical laboratories) (Lindell and Perry, 1996b). Specific information like this can help prioritize and focus mitigation efforts.

Damage assessments can also be instrumental in evidencing the economic cost associated with disaster-related hazmat incidents. At California State University, the Whittier Narrows quake resulted in fires and contamination that cost $\$ 237000$ to clean up (Lindell and Perry, 1996a). After releases during the Northridge earthquake, aerospace industrial facilities spent $\$ 50$ million on clean-up and repair costs (Lindell and Perry, 1996a). Examples like these help illustrate the high returns that mitigation and preparedness can yield. Many hazard reduction items such as gas valve shutoffs for LP gas cylinders, pipelines, appliances and equipment are relatively inexpensive. Gas utilities companies in Tokyo and Osaka have encouraged individual and industry consumers to install meters that shut off when there is an abnormally high flow rate (e.g. a pipeline rupture), when gas consumption is irregular (e.g. a gas leak) or when an earthquake is detected. The meters cost approximately US $\$ 2.00$ per month (Lindell and Perry, 1996b). Other inexpensive, effective measures include storing jars of chemicals tightly against one another and adding a 'lip' around the edge of open shelves where chemicals are stored to prevent slippage during an earthquake (Selvaduray, 1990).

Vulnerability, damage and economic assessments may not be enough to generate interest in disaster mitigation and preparedness efforts in states and disaster-prone countries that have not experienced disaster-associated hazardous material incidents. Funding and other types of support aimed at decreasing the likelihood of future events may only follow increased consideration of disaster-related hazmat issues in environmental health reviews or strategy documents (Logue, 1996). A complete, systematic assessment of hazardous material releases during natural disasters is needed to generate interest in and identify options for risk management. Establishing a uniform, centralized data collection protocol would provide organized information on the incidence and severity of events, factors that aggravate or mitigate releases, the relative effectiveness of preparedness and mitigation measures and the potential environmental and public health consequences (Lindell and Perry, 1997, 1996a).

Natural disaster-associated hazardous material releases constitute an important environmental and human health hazard. Accounts of historic incidents provide some insight into the causes and potential mitigation and prevention strategies, but additional inquiry is needed to enhance these strategies. Regional or local assessments combined with comprehensive, systematic studies will provide emergency response managers with the most effective vulnerability data upon which to base prevention and mitigation plans. Through provid- 
ing communities with accurate and appropriate information, preparedness levels and damage adsorption capacities can be raised to thwart future impacts and ensure effective responses (GuhaSapir and Lechat, 1986; Armenian, 1989).

\section{References}

Albering HJ, van Leusen SM, Moonen EJ, Hoogewerff JA, Kleinjans JC. Human health risk assessment: a case study involving heavy metal soil contamination after the flooding of the River Meuse during the winter of 1993-1994. Environ Health Perspect 1999;107:37-43.

Anderson H, Contreras J, Harmes J, Balmaseda L, Weathers D. Disaster in Mexico. Newsweek 1985; 30 September, 1622.

Anonymous. Emergency mosquito control associated with Hurricane Andrew-Florida and Louisiana, 1992. Mor Mortal Wkly Rep CDC Surveill Summ 1993;42:240-242.

Anonymous. Rapid assessment of vectorborne diseases during the Midwest Flood-United States, 1993. Mor Mortal Wkly Rep CDC Surveill Summ 1994;43:481-483.

Armenian HK. Methodologic issues in epidemiologic studies of disasters. Proceeding of the International Workshop on Earthquake Injury Epidemiology for Mitigation and Response, 10-12 July 1989, Baltimore, MD. Rockville: Technical Resources, Inc.; 1989. p. 95-106.

ABAG. Hazardous materials problems in earthquakes: background materials and database. Oakland, CA: Association of Bay Area Governments, 1990.

ATSDR. Public Health Assessment Guidance Manual. Atlanta, GA: Agency for Toxic Substances and Disease Registry (ATSDR), 2003. Available from: http://www.atsdr.cdc.gov [accessed 03 April 2003].

Baba S, Taniguchi H, Nambu S, Tsuboi S, Ishihara K, Osato S. The great Hanshin earthquake. Lancet 1996;347:307309.

Balluz L, Moll D, Diaz Martinez MG, Merida Colindres JE, Malilay J. Environmental pesticide exposure in Honduras following Hurricane Mitch. Bull World Health Organ 2001;79:288-295.

Baxter PJ. Volcanic eruptions. In: Gregg MB, French J, Binder S, Sanderson LM, editors. The public health consequences of disasters. Atlanta: US Department of Health and Human Services, 1989. p. 25-32.

Baxter PJ, Ing R, Falk H, French J, Stein GF, Bernstein RS, Merchant JA, Allard J. Mount St. Helens eruptions, May 18 to June 12, 1980: an overview of the acute health impact. J Am Med Assoc 1981;246:2585-2589.

Baxter PJ, Bernstein RS, Falk H, French J, Ing R. Medical aspects of volcanic disasters: an outline of the hazards and emergency response measures. Disasters 1982;6:268-276.

Baxter PJ, Bernstein RS, Buist AS. Preventive health measures in volcanic eruptions. Am J Public Health 1986;76:84-90.
Baxter PJ, Kapila M, Mfonfu D. Lake Nyos disaster, Cameroon, 1986: the medical effects of large scale emission of carbon dioxide? BMJ 1989;298:1437-1441.

Baxter PJ, Tedesco D, Miele G, Baubron JC, Cliff K. Health hazards of volcanic gases. Lancet 1990;336:176.

Baxter PJ. Volcanoes. In: Noji ER, editor. The public health consequences of disasters. New York: Oxford, 1997. p. 179-204.

Beardsley T. Smoke alarm: haze from fires might promote bacterial growth. Sci Am 1997;277:24-25.

Bernstein RS, Baxter PJ, Buist AS. Introduction to the epidemiological aspects of explosive volcanism. Am J Public Health 1986;76:3-9.

Binder S, Sanderson LM. The role of the epidemiologist in natural disasters. Ann Emerg Med 1987;16:1081-1084.

Boraiko AA. Earthquake in Mexico. Natl Geog 1986;655-675 (May).

Bowie P. No act of God. Amicus J 2000;22:16-21.

Breslin K. Natural disasters and man-made responses: are we protecting environmental health? Environ Health Perspect 1993;101:590-592.

Breysse PA. Health hazards of smoke. J Forest 1984;82:89.

Budyka AK, Ogorodnikov B. Radioactive aerosols formed by fires in regions polluted by products of the Chernobyl accident. Radiatsionnaia Biologiia Radioecologiia 1995;35:102-112 ([Russian] [Abstract]).

Buist AS, Bernstein RS, Johnson LR, Vollmer WM. Evaluation of physical health effects due to volcanic hazards: human studies. Am J Public Health 1986;76:66-75.

Buist AS, Martin TR, Shore JH, Butler J, Lybarger JA. The development of a multidisciplinary plan for evaluation of the long-term health effects of the Mount St. Helens eruptions. Am J Public Health 1986;76:39-44.

Duclos P, Sanderson LM, Lipsett M. The 1987 forest fire disaster in California: assessment of emergency room visits. Arch Environ Health 1990;45:53-58.

Durkin ME, Thiel CC, Schneider JE, DeVriend T. Injuries and emergency medical responses in the Loma Prieta earthquake. Bull Seismol Soc Am 1991;81:2143-2166.

Eisele JW, O'Halloran RL, Reay DT, Lindholm GR, Lewman LV, Brady WJ. Deaths during the May 18, 1980, eruption of Mount St. Helens. New Engl J Med 1981;305:931-936.

Emmanuel SC. Impact to lung health of haze from forest fires: the Singapore experience. Respirology 2000;5:175-182.

EQE International. The September 19, 1985 Mexico earthquake. Oakland, CA. Internal report; 1985.

Fields T. Hazardous releases, industrial accidents and natural hazards: the EPA's role in disasters. Nat Hazards Observer 2000;24:1-2.

Fraunfelder FT, Kalina RE, Buist AS, Bernstein RS, Johnson DS. Ocular effects following the volcanic eruptions of Mount St. Helens. Arch Ophthalmol 1983;101:376-378.

French JG, Holt KW. Floods. In: Gregg MB, French J, Binder $\mathrm{S}$, Sanderson LM, editors. The public health consequences of disasters. Atlanta: US Department of Health and Human Services, 1989. p. 69-78. 
Galgiani JN. Coccidioidomycosis: a regional disease of national importance: rethinking approaches for control. Ann Intern Med 1999;130(4):293-300.

Georgsson G, Peterson G. Fluorosis of sheep caused by the Hekla eruption in 1970. Fluoride 1972;2:58-66.

Gomez SR, Parker RA, Dosman JA, McDuffie HH. Respiratory health effects of alkali dust in residents near desiccated Old Wives Lake. Arch Environ Health 1992;47:364-369.

Green FH, Bowman L, Castranova V, Dollberg DD, Elliot JA, Fedan JS, Hahon N, Judy OJ, Major PC, Mentnech MS, Miles PR, Mull J, Olenchock S, Ong T, Pailes WM, Resnick H, Stettler LE, Tucker JG, Vallyathon V, Whong W. Health implications of the Mount St. Helen's eruption: laboratory investigations. Ann Occup Hyg 1982;26:921-933.

Gribble GW. The natural production of chlorinated compounds. Environ Sci Technol 1994;28:310A-319A.

Guha-Sapir D, Lechat MF. Information systems and needs assessment in natural disasters: an approach for better disaster relief management. Disasters 1986;10:232-237.

Gunn SWA. Multilingual dictionary of disaster medicine and international relief. Dordrecht, Netherlands: Kluwer Academic Publishers, 1990.

Hagman G. Prevention better than cure. Stockholm, Sweden: Swedish Red Cross, 1984.

IFRC. World Disasters Report 2001. Geneva, Switzerland: International Federation of Red Cross and Red Crescent Societies (IFRC); 2001.

Janerich DT, Stark AD, Greenwald P, Burnett WS, Jacobson HI, McCusker J. Increased leukemia, lymphoma, and spontaneous abortion in western New York following a flood disaster. Public Health Rep 1981;96:350-536.

Kawari M, Inoue T, Ishida Y. An autopsy case of volcanic hydrogen sulphide intoxication. Kitakanto Med J 1978;28:237-244.

Kerr RA. Nyos, the killer lake, may be coming back. Science 1989;244:1541-1542.

Kung TM, Ng WL, Gibson JB. Volcanic eruptions and carcinoma of the thyroid: a possible association. Arch Environ Health 1981;36:265-267.

Leus X, Kintanar C, Bowman V. Asthmatic bronchitis associated with a volcanic eruption in St. Vincent, West Indies. Disasters 1981;5:67-69.

Levine JS. Gaseous and particulate emissions released to the atmosphere from vegetation fires. In: Health Guidelines for Vegetation Fire Events, 6-9 October 1998, Lima, Peru. Geneva, Switzerland: World Health Organization; 1999. p. 284-299.

Lindell MK, Perry RW. Addressing gaps in environmental emergency planning: hazardous materials releases during earthquakes. J Environ Plan Manag 1996;39:529-543.

Lindell MK, Perry RW. Identifying and managing conjoint threats: earthquake-induced hazardous materials releases in the US. J Hazard Mater 1996;50:31-46.

Lindell MK, Perry RW. Hazardous materials releases in the Northridge earthquake: implications for seismic risk assessment. Risk Anal 1997;17:147-156.
Lindell MK, Perry RW. Earthquake impacts and hazard adjustment by acutely hazardous materials facilities following the Northridge earthquake. Earthquake Spectra 1998;14:285299.

Logue JN. Disasters, the environment, and public health: improving our response. Am J Public Health 1996;86:12071210.

Malilay J. Floods. In: Noji EK, editor. The public health consequences of disasters. New York: Oxford University Press, 1997. p. 287-301.

Manni C, Magalini S, Proietti R. Volcanic eruptions. In: Baskett P, Weller R, editors. Medicine for disasters. London: Wright, 1988. p. 308-317.

Mileti DS. Losses, costs, and impacts. In: Mileti DS, editor. Disasters by design: a reassessment of natural hazards in the United States. Washington, DC: Henry Joseph Press, 1999. p. $65-104$.

Nania J, Bruya TE. In the wake of Mount St. Helens. Ann Emerg Med 1982;11:184-191.

Nathan AR, Olson KR, Everson GW, Kearney TE, Blanc PD. Effects of a major earthquake on calls to regional poison control centers. West J Med 1992;156:278-280.

NIOSH. International chemical safety cards: crocidolite. Cincinnati, $\mathrm{OH}$ : National Institute for Occupational Safety and Health (NIOSH). Available from: http://www.cdc.gov/ niosh/ [accessed 03 April 2003].

Noji EK. Training of search and rescue teams for structural collapse events: a multidisciplinary approach. In: Ohata M, Ukai T, Yamamoto Y, editors. New aspects of disaster medicine. Tokyo, Japan: Herusu Publishing Co., Inc, 1989. p. $150-155$.

Noji EK. Natural disasters. Crit Care Clin 1991;7:271-292.

Noji EK. The nature of disaster: general characteristics and public health effects. In: Noji ER, editor. The public health consequences of disasters. New York: Oxford, 1997. p. 320.

Nukushina J. Japanese earthquake victims are being exposed to high density of asbestos: we need protective masks desperately. Epidemiol Prev 1995;19:226-227.

Nyman DJ, Prosser WJ, Moriwaki Y, O'Rourke TD. Earthquake vulnerability assessment of a 40-inch crude oil pipeline in the central United States. In: Tierney KJ, Nigg JM, editors. Proceedings of the 1993 National Earthquake Conference: Earthquake Hazard Reduction in the Central and Eastern United States, 2-5 May 1993, vol. 2. Memphis, TN. Memphis: Central United States Earthquake Consortium; 1993. p. 587-596.

OUSFDA. Disaster history: significant data on major disasters worldwide, 1900-present. Washington, DC: Office of US Foreign Disaster Assistance (OUSFDA), 1995.

Olsen KB, Fruchter JS. Identification of the physical and chemical characteristics of volcanic hazards. Am J Public Health 1986;76:45-52.

Orlowskii J. Floods, hurricanes and tsunamis. In: Weller RO, Baskett PJ, editors. Medicine for disasters. London: Wright, 1988. p. 291-307. 
Perry JA. Pesticide and PCB residues in the upper Snake River ecosystem, Southeastern Idaho, following the collapse of the Teton Dam 1976. Arch Environ Contam Toxicol 1979;8:139-159.

PANNA. Pesticides on European Beaches. San Francisco, CA: Pesticide Action Network North America (PANNA). Available from: http://www.panna.org [accessed 03 April 2003].

Picard J. Flood debris pulled from river. Bridgewater, NJ: The Courier News, 1999. p. 22

Robinson A. Earthshock: hurricanes, volcanic eruptions, earthquakes, tornadoes and other forces of nature. London: Thames and Hudson Ltd, 1993.

Sanderson LM. Toxicologic disasters: natural and technologic. In: Sullivan JB, Krieger GR, editors. Hazardous materials toxicology: clinical principles of environmental health. Baltimore, MD: Williams, 1992. p. 326-331.

Schmidt CW. Lessons from the flood: will Floyd change livestock farming? Environ Health Perspect 2000;108:A74A77.

Schneider E, Hajjeh RA, Spiegel RA, Jibson RW, Harp EL, Marshall GA, Gunn RA, McNeil MM, Pinner RW, Baron RC, Burger RC, Hutwagner LC, Crump C, Kaufman L, Reef SE, Feldman GM, Pappagianis D, Werner SB. A coccidioidomycosis outbreak following the Northridge, Calif, earthquake. J Am Med Assoc 1997;277:904-908.

Schwela DH, Goldammer JG, Morawska LH, Simpton O, editors. WHO health guidelines for vegetation fire events. Singapore: Public Institute of Environmental Epidemiology, Ministry of the Environment, 1999.

Selvaduray G. Earthquake hazard reduction at Japanese petroleum production facilities. Proceedings of the Third US Conference on Earthquake Engineering, Charleston, SC; August 1986. p. 2119-2130.

Selvaduray G. Development of earthquake hazard reduction equipment in Japan. Proceedings of the Third US Conference on Earthquake Engineering, Charleston, SC; August 1986. p. 2413-2420.

Selvaduray G. Reducing earthquake-caused damage at industrial facilities. Proceedings of the First National Conference of DRP, American Defense Preparedness Association, Los Angeles, CA; April 10-11, 1990. p. 56-67.

Showalter PS, Myers MF. Natural disasters in the United States as release agents of oil, chemicals, or radiological materials between 1980-1989: analysis and recommendations. Risk Anal 1994;14:169-182.

Sigurdsson B, Palsson PA. Fluorosis of farm animals during the eruption of Hekla 1947-1948. In: Einarsson T, Kjartansson G, Thórarinsson S, editors. The eruption of Hekla 1947-1948, part 3. Reykajvik: H.F. Leiftur, 1957. p. 1-12.

Simons M. Deadly flotsam on French shores. New York City, NY: New York Times, 1993; 28 December: A7.

Singh G, Kathpal TS, Kushwaha KS, Yadav GS. Persistence of aldrin in flooded soil under the cover of rice. Ecotox Environ Safe 1985;9:294-299.

Steinbrugge KV, Lagorio HJ, Davis JR, Bennett JH, Borchardt G. Earthquake planning scenario for a magnitude 7.5 earth- quake on the Hayward fault, San Francisco Bay area California. Geology 1986;397:153-157.

SLUEC. Recent Midwest Earthquakes. St. Louis, MO: St. Louis University Earthquake Center (SLUEC). Available from: http://www.eas.slu.edu/ [accessed 03 April 2003].

Stratton JW. Earthquakes. In: Gregg MB, French J, Binder S, Sanderson LM, editors. The public health consequences of disasters. Atlanta: US Department of Health and Human Services, 1989. p. 13-24.

Swinbanks D. Forest fires cause pollution crisis in Asia. Nature 1997;389:321.

Thomas VM, Holt CL. The degradation of $\left[{ }^{14} \mathrm{C}\right]$ molinate in soil under flooded and nonflooded conditions. J Environ Sci Health B 1980;15:475-484.

Thórarinsson S. On the damage caused by volcanic eruptions with special reference to tephra and gases. In: Sheets PD, Grayson D, editors. Volcanic activity and human ecology. New York: Academic Press Inc, 1979. p. 125-159.

Tierney KJ. Secondary hazards resulting from earthquakes: hazardous materials emergencies and high-rise fires. Urban Resources 1989;5:33-36.

US EPA. Environmental Protection Agency Pacific Northwest Region Environmental Quality Profile. Washington, DC: US Environmental Protection Agency, 1980.

US EPA. Environmental Protection Agency Office of Solid Waste and Emergency Response (5101) EPA 550-F-93-002. Washington, DC: US Environmental protection Agency, 1993.

Ward DE. Air toxics and fireline exposure. In: McIver DC, Auld H, Whitewood R, editors. The Tenth Conference on Fire and Forest Meteorology, 17-21 April 1989, Ottawa, Canada: Forestry Canada, 1989. p. 184-193.

Ward DE. Review of smoke components. In: Sharkey B, editor. Health Hazards of Smoke. Recommendations of the Consensus Conference, April 1997, Missoula, MT: US Department of Agriculture Forest Service; 1997. p. 84.

WBG. Greening industry: new roles for communities, markets, and governments. A World Bank Policy Research Report. Washington, DC: The World Bank Group-Development Economics (WBG), 2000.

Werner SD, Boutwell SH, Varner TR. Identification and mitigation of potential earthquake induced hazardous material incident in Silicon Valley facilities. Proceedings of the Hazmacon Conference, 18-20 April, 1989, Santa Clara, CA. Los Angeles: Dames \& Moore; 1989. p. 1-11.

Wijkman A, Timberlake L. Natural disasters: acts of God or acts of man. New York: Earthscan Paperback, 1984.

White K. Signs of an olive branch: confronting the environmental health consequences of the Midwestern floods. Environ Health Perspect 1993;101:584-588.

Whitman RV. The prognosis for earthquake hazard mitigation. Proceedings of the Third US Conference on Earthquake Engineering. Charleston, SC; August, 1986. p. 2617-2629.

World Health Organization (WHO). Emergency care in natural disasters: views of an international seminar. WHO Chronicles 1980;34:96-100.

Ziegler JL. Endemic Kaposi's sarcoma in Africa and local volcanic soils. Lancet 1993;342:1348-1351. 